\title{
Two Clocks: A Comparison of Ceramic and Radiocarbon Dates at Macapainara, East Timor
}

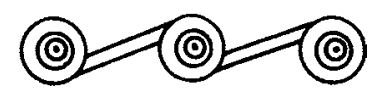

JACK N. FENNER AND DAVID BULBECK

A man with a clock knows the time. A man with two clocks is never sure.

- Proverb

ARTIFACT AND SITE DATING is crucial to archaeological investigations, so archaeologists have developed many techniques for determining when particular objects or locations were in use. For dating late Holocene sites, radiocarbon dating and ceramic typology assessment are two of the most common techniques. Radiocarbon dating is often considered the gold standard because it provides an absolute date with known precision, depends on well-understood physical properties, and has a long history of successful use. Radiocarbon dating does, however, present problems in some circumstances. It is fairly expensive and requires the preservation and recovery of organic material. When organic material is recovered, it may be difficult to assess whether the material is naturally occurring or directly associated with the human occupation of interest. Similarly, redeposition or stratigraphic disturbance may produce false associations between the material and the cultural sequence within a site.

Ceramic typology was one of the main tools used by archaeologists to date sites prior to the widespread availability of radiocarbon dating. It can be as accurate and precise as radiocarbon dating in circumstances where the ceramic sequence is well understood and varies rapidly through time. It has the further advantages that ceramics are necessarily anthropogenic and often a large sample is available. Ceramic assessment is usually inexpensive in terms of direct funding cost; however it can be performed only by experts in the types of ceramics found at the site, and the initial effort involved in defining the types and establishing their age ranges is substantial. Ceramic analysis is, of course, only possible when investigating ceramics-using cultural groups. Furthermore, the variation in manufacturing volume and transport durations during a ceramic type's age range are usually unknown, so distribution functions of intra-range probability cannot be constructed and age range precision is uncertain. Ceramic distribution functions are nevertheless commonly assumed to be

Jack N. Fenner is a Research Fellow in Archaeology and Natural History at The Australian National University, Canberra, Australia. David Bulbeck is a Senior Research Associate in Archaeology and Natural History at The Australian National University, Canberra, Australia. 
uni-modal (e.g., frequency seriation dating [Dunnell 1970]) and symmetric (e.g., South's [1977:210-212] mean ceramic date typologies). Finally, ceramics are subject to the same redeposition and stratigraphic disturbance association problems as are radiocarbon organics.

The two techniques thus share some difficulties but are largely independent means of dating archaeological materials. In this article, we present a series of radiocarbon and ceramic typology dates from the Macapainara site in East Timor. Despite being derived from the same excavation pits within a single site and supposedly dating the same occupation sequence, the two techniques produce substantially different time sequences. We will assess the potential sources of this discrepancy, and consider the implications for dating other sites in East Timor and throughout the Island Southeast Asian region.

\section{MACAPAINARA}

The archaeological site of Macapainara is located in eastern East Timor, about one km inland from the ocean (Fig. 1). It is one of many archaeological sites in East Timor that are interpreted as fortified, defensive occupation areas because of the presence of large stone walls around their perimeters and defensive situations above steep slopes or gullies (Lape 2006; Lape and Chin-Yung 2008; O'Connor et al. 2012). Some researchers attribute the rise of fortifications in East Timor and indeed throughout Island Southeast Asia at least in large part to conflict associated with climate changes driven by El Niño Southern Oscillation changes starting about A.D. 1000 (Field and

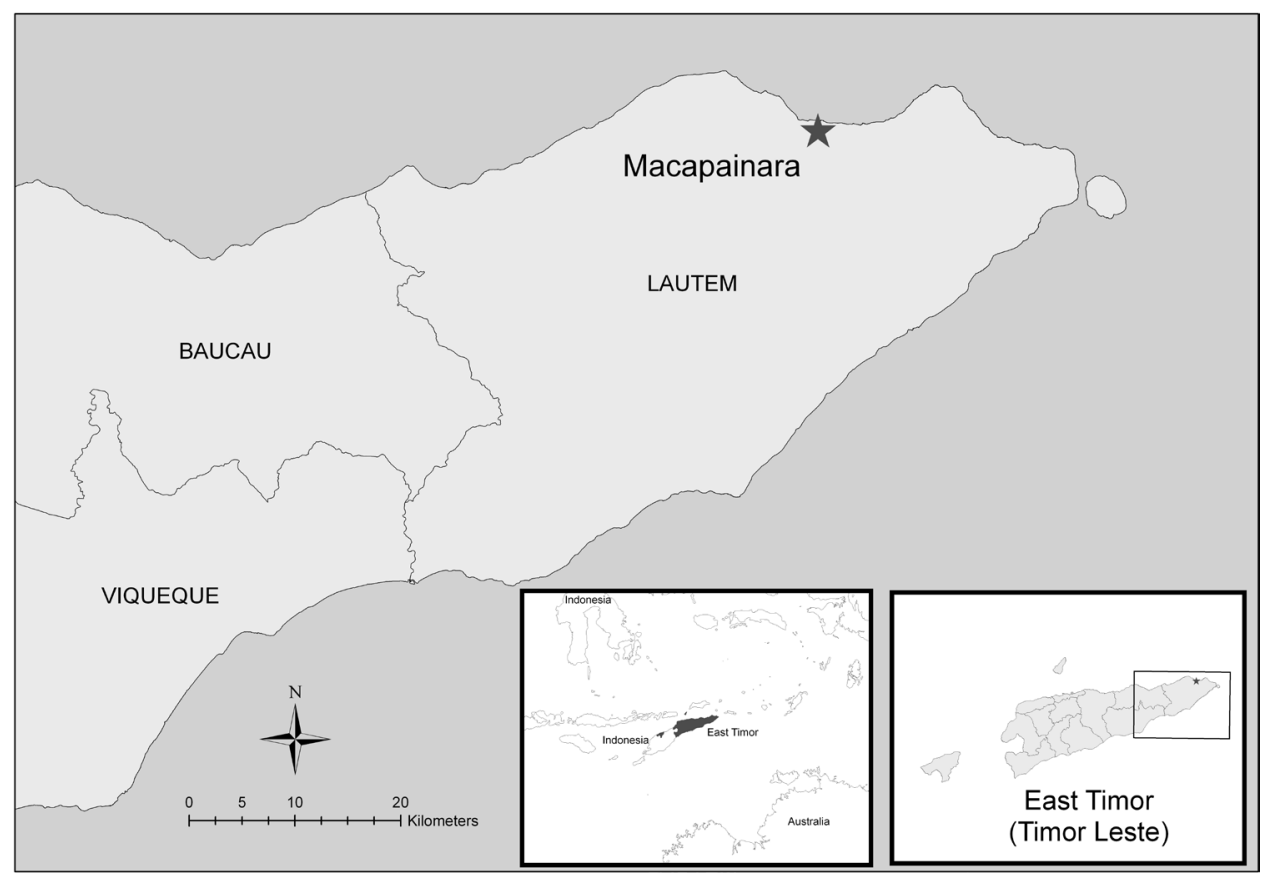

Fig. 1. Macapainara site location. 
Lape 2010; Lape and Chin-Yung 2008). Others propose that fortifications are more likely to be a direct or indirect response to European impact, and especially as a reaction against slave raids (cf. O'Connor et al. 2012). This latter hypothesis would imply a post-A.D. 1500 date, with raiding likely to have peaked in the eighteenth to nineteenth centuries (Reid 1983). Thus the initial date of occupation at Macapainara and other fortified sites is crucial to assessing which, if either, of these two proposals is correct.

Macapainara was excavated in 2008 by a team led by Sue O'Connor and Celia Brockwell of The Australian National University (O'Connor et al. forthcoming). They excavated three pits, labeled pits A, C, and D. An abundance of stones and a lack of discernable change in deposition meant that the excavators were unable to follow natural stratigraphy so the pits were dug in arbitrary $5 \mathrm{~cm}$ spits (Celia Brockwell, pers. comm. 2010). Materials recovered include large quantities of stone, local earthenware pottery, and faunal refuse including marine shell. The site also yielded small amounts of charcoal, beads of glass and other materials, and fragments of bottle glass and highfired (exotic) ceramics. Each pit was dug to below cultural occupation level.

\section{Radiocarbon Analysis}

Nine pieces of charcoal were collected in situ for radiocarbon analysis, with three from each of the three excavation pits (Table 1). This includes one sample from the lowest cultural layer in each pit. The species represented were not identified. Charcoal was not abundant, with only $150 \mathrm{~g}$ collected in total. No hearths or other burnt features were encountered. Marine shell was also collected from each pit and submitted

Table i. Macapainara Radiocarbon Dates

\begin{tabular}{|c|c|c|c|c|}
\hline SAMPLE & MATERIAL & LAB ID & $\begin{array}{l}\text { RADIOCARBON } \\
\text { DATE (RCYBP) }\end{array}$ & CALIBRATED DATE RANGE (A.D.) \\
\hline $\mathrm{A} 2 \mathrm{c}$ & Charcoal & WK24947 & $54 \pm 30$ & 1809 to 1837,1845 to 1858,1880 to 1922 \\
\hline $\mathrm{A} 8 \mathrm{c}$ & Charcoal & WK24948 & $83 \pm 30$ & 1806 to 1840,1842 to 1867,1876 to 1923 \\
\hline A13c & Charcoal & WK24949 & $221 \pm 30$ & $\begin{array}{l}1666 \text { to } 1683,1725 \text { to } 1814,1836 \text { to } 1849, \\
1855 \text { to } 1879\end{array}$ \\
\hline $\mathrm{C} 2 \mathrm{c}$ & Charcoal & WK24950 & $107 \pm 30$ & 1804 to 1923 \\
\hline $\mathrm{C} 7 \mathrm{c}$ & Charcoal & WK24951 & $72 \pm 30$ & 1808 to 1839,1844 to 1866,1878 to 1923 \\
\hline $\mathrm{C} 13 \mathrm{c}$ & Charcoal & WK24952 & $282 \pm 30$ & 1644 to 1665,1739 to 1801 \\
\hline D2c & Charcoal & WK24953 & $49 \pm 30$ & 1809 to 1838,1880 to 1922 \\
\hline D8c & Charcoal & WK24954 & $193 \pm 37$ & 1721 to 1897,1920 to 1932 \\
\hline D15c & Charcoal & WK24955 & $93 \pm 30$ & 1806 to 1870,1876 to 1924 \\
\hline $\mathrm{A} 2 \mathrm{~s}$ & Seashell & WK24956 & $563 \pm 30$ & Not calibrated \\
\hline A $8 \mathrm{~s}$ & Seashell & WK24957 & $709 \pm 33$ & Not calibrated \\
\hline A13s & Seashell & WK24958 & $771 \pm 34$ & Not calibrated \\
\hline $\mathrm{C} 2 \mathrm{~s}$ & Seashell & WK24959 & $599 \pm 40$ & Not calibrated \\
\hline $\mathrm{C} 7 \mathrm{~s}$ & Seashell & WK24960 & $778 \pm 35$ & Not calibrated \\
\hline C13s & Seashell & WK24961 & $778 \pm 42$ & Not calibrated \\
\hline D2s & Seashell & WK24962 & $684 \pm 35$ & Not calibrated \\
\hline D8s & Seashell & WK24963 & $660 \pm 30$ & Not calibrated \\
\hline D15s & Seashell & WK24964 & $964 \pm 30$ & Not calibrated \\
\hline
\end{tabular}

Adapted from Fenner et al. (forthcoming). Seashell is not calibrated due to uncertainty in the local $\Delta \mathrm{R}$. 
for radiocarbon analysis. However, the radiocarbon calibration change due to oceanic upwelling $(\Delta \mathrm{R})$ is not known for the area so these marine shell dates cannot be assigned absolute dates or used for comparison to other sites. The shell dates were used, however, to help assess excavation pit stratigraphic integrity. All radiocarbon dates are AMS dates performed by Waikato Radiocarbon Dating Lab. They were calibrated using the BCal calibration tool (Buck et al. 1999) with the SHCal04 southern hemisphere calibration curve (McCormac et al. 2004). (BCal is a Bayesian radiocarbon calibration service available online at http://bcal.shef.ac.uk/.) Calibrated date ranges shown are the 95 percent highest probability density regions. Bayesian analysis of the nine charcoal radiocarbon results indicate that Macapainara was most likely first occupied between A.D. 1695 and 1780, and almost certainly post-dates A.D. 1600 (97\% probability) (Fenner et al. forthcoming). It was not abandoned until the midtwentieth century or later.

\section{Ceramic Analysis}

Ceramic typology assessment was performed by one of this article's authors (David Bulbeck, DB) based on previous experience with identifying large collections of stoneware and porcelain imported into South Sulawesi, which lies northwest of East Timor (Bulbeck 1992; Bulbeck and Caldwell 2000). DB also studied the $31.7 \mathrm{~kg}$ of earthenware pottery recovered from Macapainara, accounting for 1.3 percent of excavated sediment weight. The most common forms are small, medium, and large jars, as well as plates and bowls - that is, storage, cooking, and serving vessels that would have satisfied the needs of the Macapainara inhabitants for their utilitarian crockery. Although the earthenware pottery is not independently dated, and so cannot be included in our chronometric analysis, it is worth noting that the jar rim shapes show a transition from predominantly rounded rims in the lower spits (9 to 15) to a wide variety of shapes, especially upturned rims, in the upper spits (1 to 8$)$.

The site's small assemblage of high-fired ceramics ( $<150 \mathrm{~g}$ total) is readily distinguishable from the local earthenware on the basis of a stoneware or porcelain body and, in most cases, a glazed surface. High-fired ceramic potsherds are considered to be from the same vessel if their type classification, form, fabric, and glaze colors match, and they were found in the same or adjoining spits. Potsherds from the same vessel necessarily date to the same period and so are combined for our analysis. Detailed description of the analysis procedure and resulting identifications is available in Bulbeck (2010).

Sixty potsherds from 49 vessels were recovered from the three excavation pits (Table 2). Ceramics were found from spit 1 to spit 11, but end above the lowest cultural level in each pit. The ceramic dates range from c. A.D. 1500 to 1900, with most being prior to 1800. Most are of Chinese origin, but the assemblage also includes ceramics from two or three other regions in Southeast Asia plus Europe (Fig. 2). There is no clear temporal correlation with source area, except that the European potsherds all post-date A.D. 1725 .

\section{Ceramic and Radiocarbon Comparison}

We propose to compare ceramic and radiocarbon date sequences through time to identify differences in date estimation. This requires that the sequences be in correct 
Table 2. Ceramic Typology Classification and Date Estimates

\begin{tabular}{|c|c|c|c|c|c|c|}
\hline $\begin{array}{l}\text { VESSEL } \\
\text { ID }\end{array}$ & PIT & SPIT & $\begin{array}{l}\text { POTSHERDS } \\
\text { PER VESSEL }\end{array}$ & CLASSIFICATION & $\begin{array}{l}\text { AGE ESTIMATE } \\
\text { (CENTURY A.D.) }\end{array}$ & $\begin{array}{l}\text { VESSEL } \\
\text { FORM }\end{array}$ \\
\hline $\mathrm{A} 1 \mathrm{v}$ & A & 1 & 1 & $\begin{array}{l}\text { Chinese Transitional cf. Jiajing (blue } \\
\text { and white) }\end{array}$ & Mid-17th & Bowl \\
\hline $\mathrm{A} 2 \mathrm{v}$ & A & 2 & 1 & Chinese Ming/Transitional (plainware?) & 16th-17th & Bowl \\
\hline $\mathrm{A} 3 \mathrm{v}$ & A & 2 & 1 & $\begin{array}{l}\text { Chinese pseudomorph Swatow (blue } \\
\text { and white) }\end{array}$ & Late 17 th & Bowl \\
\hline $\mathrm{A} 4 \mathrm{v}$ & A & 2 & 1 & Chinese Swatow (plainware?) & 17 th & Open \\
\hline $\mathrm{A} 5 \mathrm{v}$ & A & 2 & 1 & $\begin{array}{l}\text { Chinese early Qing (red overglaze } \\
\text { decorated) }\end{array}$ & $\begin{array}{l}\text { Late } 17 \text { th- } \\
\quad \text { early } 18 \text { th }\end{array}$ & Tile \\
\hline A $6 v$ & A & 2 & 1 & Chinese early Qing (blue and white) & $\begin{array}{l}\text { Late } 17 \text { th- } \\
\quad \text { early } 18 \text { th }\end{array}$ & Bowl \\
\hline $\mathrm{A} 7 \mathrm{v}$ & A & 2 & 1 & Thai Singburi (unglazed) & 16 th-17th & Jar \\
\hline A $8 v$ & A & 2,3 & 5 & $\begin{array}{l}\text { Chinese early Qing (copper spotted } \\
\text { underglaze) }\end{array}$ & $\begin{array}{l}\text { Late } 17 \text { th- } \\
\quad \text { early } 18 \text { th }\end{array}$ & Jarlet \\
\hline $\mathrm{A} 9 \mathrm{v}$ & A & 3 & 1 & Vietnam monochrome (brownware) & 16 th-17th & Jarlet \\
\hline $\mathrm{A} 10 \mathrm{v}$ & A & 4 & 1 & Vietnam monochrome (greenware) & 16th-17th & Bowl \\
\hline A11v & A & 4 & 1 & Chinese Transitional (blue and white) & 17 th & Bowl \\
\hline $\mathrm{A} 12 \mathrm{v}$ & A & 7 & 1 & European (painted blue and white) & Mid-18th & Tallish \\
\hline $\mathrm{A} 14 \mathrm{v}$ & A & 7 & 1 & Thai Singburi (blackware) & 16th-17th & Jar \\
\hline $\mathrm{A} 15 \mathrm{v}$ & A & 7 & 1 & Chinese Ming (blue and white) & 16th & Open \\
\hline A16v & A & 7 & 1 & Chinese early Qing (greenware) & $\begin{array}{l}\text { Late } 17 \text { th- } \\
\quad \text { early } 18 \text { th }\end{array}$ & Jar \\
\hline $\mathrm{A} 17 \mathrm{v}$ & A & 7 & 1 & Chinese early Qing (whiteware) & $\begin{array}{l}\text { Late } 17 \text { th- } \\
\quad \text { early } 18 \text { th }\end{array}$ & Closed \\
\hline $\mathrm{A} 18 \mathrm{v}$ & A & 9 & 1 & Thailand/Cambodia coarse brown & 16 th-17th & Jar \\
\hline $\mathrm{A} 19 \mathrm{v}$ & A & 9 & 1 & Vietnam coarse red & 17th-18th & Jar \\
\hline $\mathrm{A} 20 \mathrm{v}$ & A & 10 & 3 & Chinese Ming Swatow (blue and white) & 16th & Dish \\
\hline $\mathrm{A} 21 \mathrm{v}$ & A & 10 & 1 & Chinese Ming (blue and white) & 16th & Plate \\
\hline $\mathrm{A} 22 \mathrm{v}$ & A & 10 & 1 & $\begin{array}{l}\text { South China/Vietnam brittle } \\
\text { (brownware) }\end{array}$ & 16th & Jar \\
\hline $\mathrm{A} 23 \mathrm{v}$ & A & 11 & 1 & $\begin{array}{l}\text { Chinese Ming (green overglaze } \\
\text { decorated) }\end{array}$ & Early 16 th & Jarlet \\
\hline $\mathrm{C} 1 \mathrm{v}$ & $\mathrm{C}$ & 2 & 4 & Chinese Qing (whiteware) & 18th & Bowl \\
\hline $\mathrm{C} 2 \mathrm{v}$ & $\mathrm{C}$ & 2 & 1 & Chinese Qing (blue and white) & Late 18th & Closed \\
\hline $\mathrm{C} 3 \mathrm{v}$ & $\mathrm{C}$ & 2 & 1 & Chinese Qing Swatow (blue and white) & $\begin{array}{l}\text { Late } 17 \text { th- } \\
\quad \text { early } 18 \text { th }\end{array}$ & Jar \\
\hline $\mathrm{C} 4 \mathrm{v}$ & $\mathrm{C}$ & 8 & 1 & Chinese Swatow (plainware) & 17 th & Open \\
\hline $\mathrm{C} 5 \mathrm{v}$ & $\mathrm{C}$ & 9 & 1 & Chinese Ming (blue and white) & 16th & Plate \\
\hline C6v & $\mathrm{C}$ & 9 & 1 & $\begin{array}{l}\text { Chinese Ming/Transitional (blue and } \\
\text { white) }\end{array}$ & 16 th-17th & Bowl \\
\hline $\mathrm{C} 8 \mathrm{v}$ & $\mathrm{C}$ & 10 & 1 & Chinese Ming Swatow (blue and white) & 16th & Open \\
\hline $\mathrm{C} 9 \mathrm{v}$ & $\mathrm{C}$ & 11 & 2 & $\begin{array}{l}\text { Chinese Swatow/Ming Swatow } \\
\text { (plainware?) }\end{array}$ & 16th-17th & Open \\
\hline $\mathrm{D} 1 \mathrm{v}$ & $\mathrm{D}$ & 1 & 1 & European (printed blue and white) & Early 19 th & Plate \\
\hline $\mathrm{D} 2 \mathrm{v}$ & $\mathrm{D}$ & 2 & 1 & European (creamware) & Late 18 th & Teapot \\
\hline $\mathrm{D} 3 \mathrm{v}$ & $\mathrm{D}$ & 2 & 1 & Chinese early Qing (blue and white) & $\begin{array}{l}\text { Late } 17 \text { th }- \\
\quad \text { early } 18 \text { th }\end{array}$ & Open \\
\hline $\mathrm{D} 4 \mathrm{v}$ & $\mathrm{D}$ & 2 & 1 & Vietnam (blue and white) & 19th & Tea tray \\
\hline D6v & $\mathrm{D}$ & 4 & 1 & Chinese Ming (blue and white) & Late 16 th & Plate \\
\hline $\mathrm{D} 7 \mathrm{v}$ & $\mathrm{D}$ & 5 & 1 & Chinese Qing (blue and white) & Late 18 th & Bowl \\
\hline D8v & $\mathrm{D}$ & 5 & 1 & Chinese Qing (brownware) & 19th & Bowl \\
\hline
\end{tabular}


TABLE 2 (Continued)

\begin{tabular}{|c|c|c|c|c|c|c|}
\hline $\begin{array}{l}\text { VESSEL } \\
\text { ID }\end{array}$ & PIT & SPIT & $\begin{array}{l}\text { POTSHERDS } \\
\text { PER VESSEL }\end{array}$ & CLASSIFICATION & $\begin{array}{l}\text { AGE ESTIMATE } \\
\text { (CENTURY A.D.) }\end{array}$ & $\begin{array}{l}\text { VESSEL } \\
\text { FORM }\end{array}$ \\
\hline $\mathrm{D} 9 \mathrm{v}$ & $\mathrm{D}$ & 7 & 1 & Chinese late Ming (blue and white) & $\begin{array}{l}\text { Late } 16 \text { th- } \\
\quad \text { early } 17 \text { th }\end{array}$ & Jar \\
\hline $\mathrm{D} 10 \mathrm{v}$ & $\mathrm{D}$ & 7 & 1 & Vietnam monochrome (greenware) & 16th-17th & $\begin{array}{l}\text { Lime } \\
\text { pot }\end{array}$ \\
\hline $\mathrm{D} 11 \mathrm{v}$ & $\mathrm{D}$ & 8 & 1 & $\begin{array}{l}\text { Chinese Kraaksporselein (blue and } \\
\text { white) }\end{array}$ & 17 th & Plate \\
\hline $\mathrm{D} 12 \mathrm{v}$ & $\mathrm{D}$ & 8 & 1 & $\begin{array}{l}\text { Chinese Kraaksporselein (blue and } \\
\text { white) }\end{array}$ & $\begin{array}{l}\text { 17th-early } \\
\text { 18th }\end{array}$ & Plate \\
\hline D13v & $\mathrm{D}$ & 9 & 3 & Chinese Guangdong (blackware) & 19th & Jar \\
\hline $\mathrm{D} 14 \mathrm{v}$ & $\mathrm{D}$ & 10 & 1 & Thailand/Cambodia coarse brown & 16th-17th & Jar \\
\hline D15v & $\mathrm{D}$ & 11 & 1 & Chinese Ming Swatow (blue and white) & 16th & Dish \\
\hline D16v & $\mathrm{D}$ & 11 & 1 & Chinese Swatow (blue and white) & 17 th & Open \\
\hline
\end{tabular}

Note: Excludes four vessels with age range estimates greater than 200 years. See Bulbeck (2010) for detailed classification procedure and discussion.

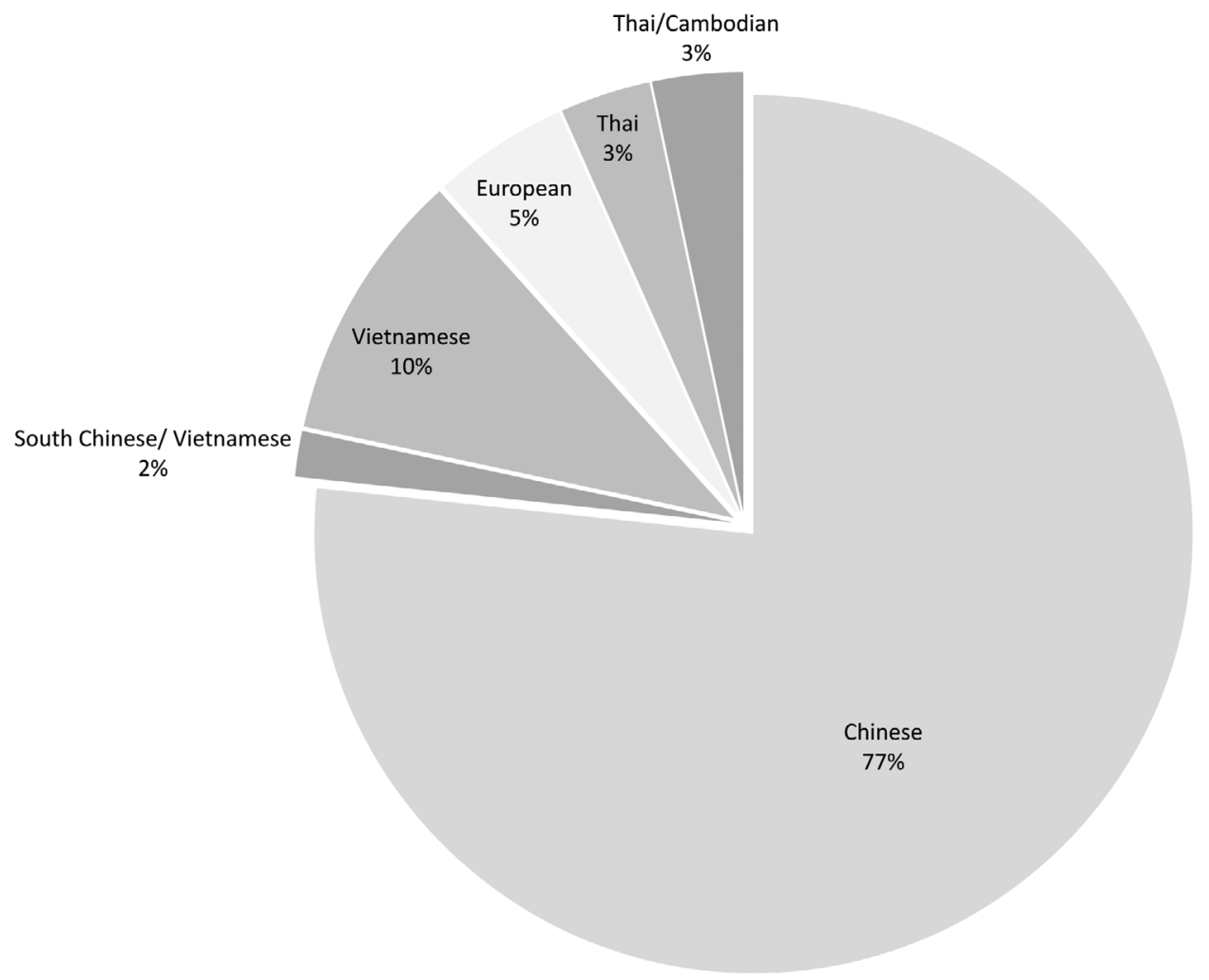

Fig. 2. Macapainara vessel source locations. Includes pits A, C, and D. 


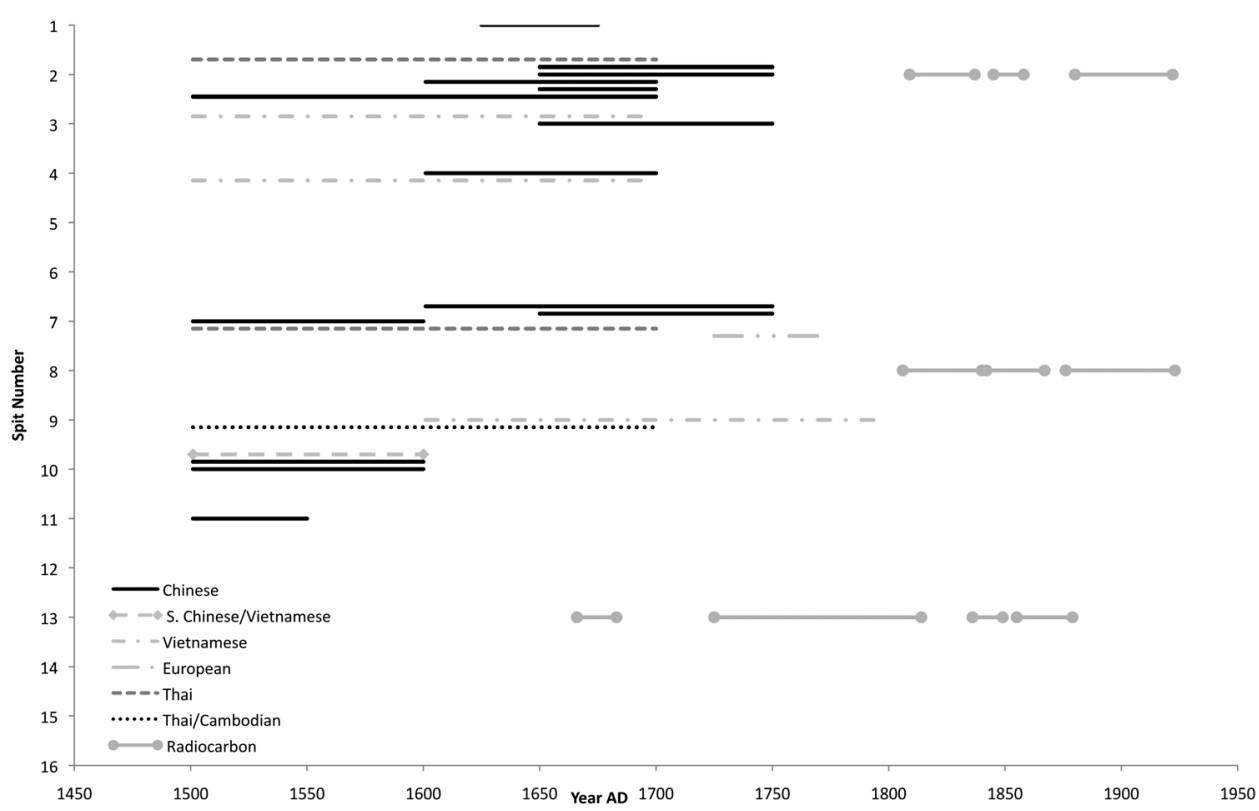

Fig. 3. Stratigraphic locations and date assignments of Macapainara Pit A ceramics and radiocarbondated charcoal. The ground surface is at the top of Spit 1 , and each spit was approximately $5 \mathrm{~cm}$ in depth. The position of ceramics within a spit was not recorded; the relative vertical positions within a spit shown here are arbitrary and for illustrative purposes only.

relative order; that is, the stratigraphic integrity must be good so that date comparisons between artifacts from the same or adjacent spits correctly compare artifacts from the same or adjacent time periods. Because stratigraphy was not visible during excavation, stratigraphic integrity must be checked using the date sequences themselves. Figure 3 shows the ceramic typology dates and radiocarbon dates in stratigraphic order by spit number for excavation pit A. Inspecting the radiocarbon sequence, it is clear that the three radiocarbon dates are in reasonable stratigraphic order; a lefttrending line can be drawn from the top to the bottom through all three dates without requiring any "jogs" to the right. The ceramic dates also appear to be in reasonable stratigraphic order, with only the single European potsherd in spit 7 seeming to be slightly out of sequence. Likewise, excavation pit C appears to be in good stratigraphic order (Fig. 4).

Excavation pit D (Fig. 5), on the other hand, has a number of dates that are inconsistent with good stratigraphic integrity. A left-trending line can be drawn through the radiocarbon dates so technically they are in stratigraphic order, but the sample from spit 15 (sample id D15c) seems suspiciously late in time. More importantly, the ceramic date from spit 9 is clearly out of sequence, as are either the two dates from spit 5 or the date from spit 4 . This is not proof of stratigraphic displacement, as the earlier dated potsherds higher in square D could be from vessels that were centuries-old antiques kept at Macapainara during its last phase of habitation, but it is suspicious. As a further check, we can consider the uncalibrated radiocarbon dates from nine shellderived radiocarbon dates (Table 1). They are in reasonable stratigraphic order for all three pits, although the mean values of pit D samples D2s and D8s are reversed from 


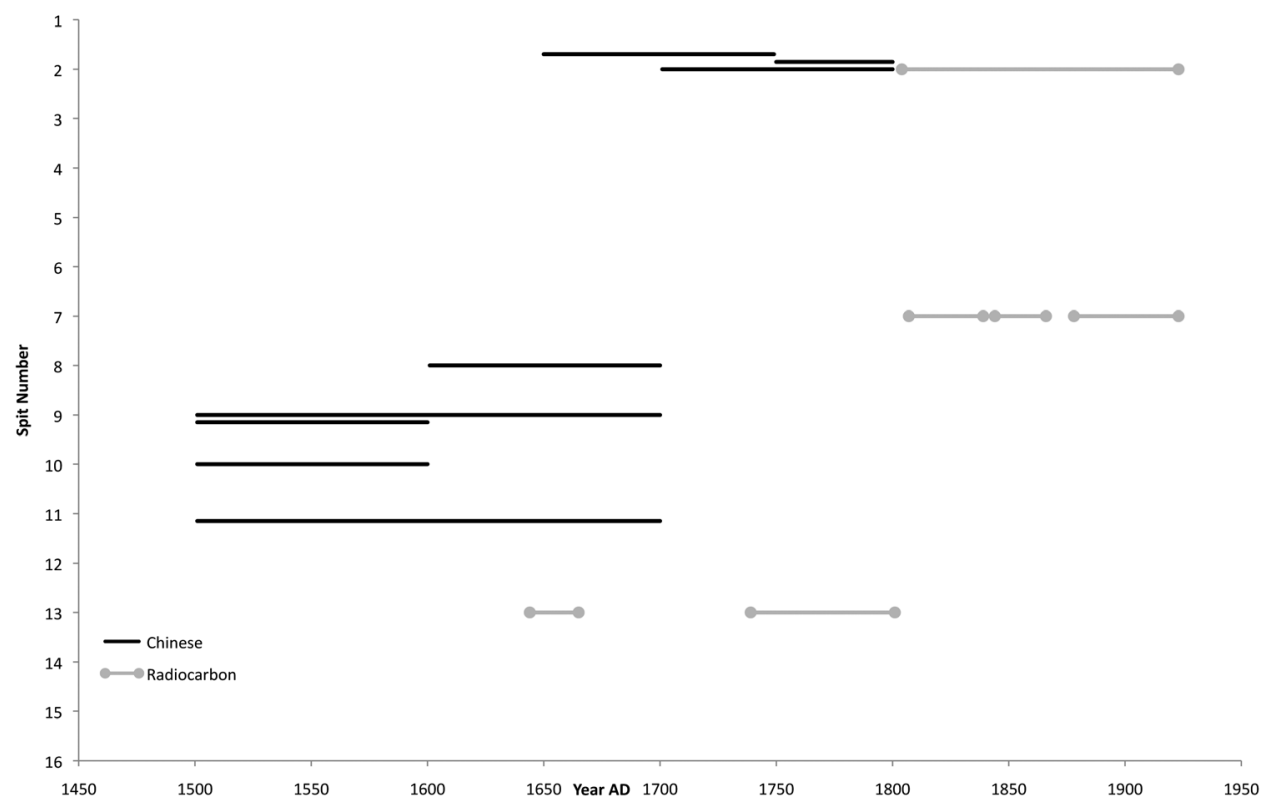

Fig. 4. Stratigraphic locations and date assignments of Macapainara Pit C ceramics and radiocarbondated charcoal. The ground surface is at the top of Spit 1, and each spit was approximately $5 \mathrm{~cm}$ in depth. The position of ceramics within a spit was not recorded; the relative vertical positions within a spit shown here are arbitrary and for illustrative purposes only.

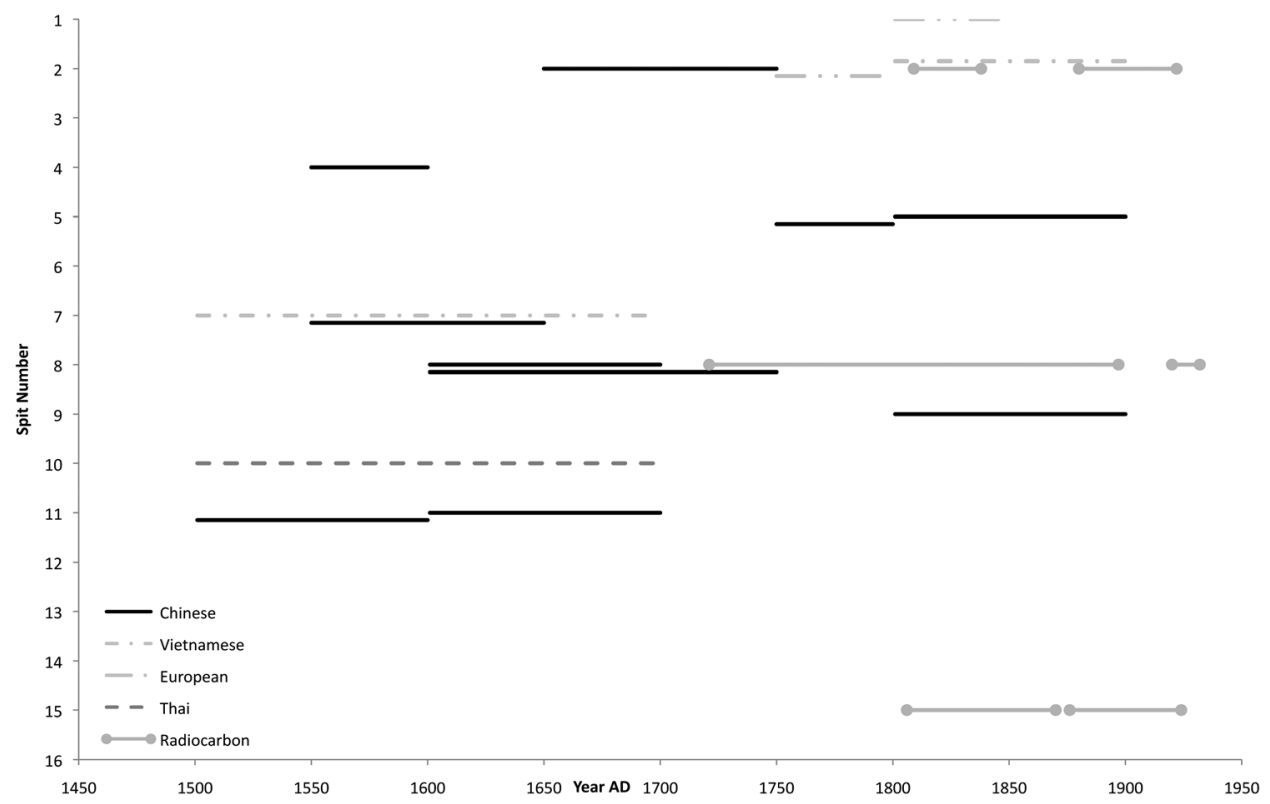

Fig. 5. Stratigraphic locations and date assignments of Macapainara Pit D ceramics and radiocarbondated charcoal. The ground surface is at the top of Spit 1, and each spit was approximately $5 \mathrm{~cm}$ in depth. The position of ceramics within a spit was not recorded; the relative vertical positions within a spit shown here are arbitrary and for illustrative purposes only. 
the expected order. Due to stratigraphic integrity concerns, excavation pit D will be excluded from further analysis.

\section{Date Comparison}

No radiocarbon date overlaps a ceramic date from the same spit or adjoining spits in either pit A or C (Figs. 3, 4). Sometimes there is a large time gap (e.g., pit A spit 2) while in other cases the gap is small or the dates adjacent (pit $\mathrm{C}$ spit 2), but never do they overlap as one would expect if they were dating the same events. Radiocarbon and ceramics are therefore producing different dates from the same occupation, with the ceramic dates always earlier in time than the radiocarbon dates.

Quantifying the date difference is difficult because of uncertainty in the precision of each technique. One approach to quantifying the difference is to evaluate the difference in the midpoints of the date ranges for materials in the same or adjacent spits. For calibrated radiocarbon dates, the midpoint of a date range is the year in which the area under its posterior probability density distribution curve reaches 50 percent. That is, the year for which there is a 50 percent probability that the date is earlier, and a 50 percent probability that the date is later. Determining a midpoint for ceramic dates is more difficult because the probability distribution represented by our ceramic date ranges is unknown. There is no literature we are aware of to document the ceramic production from China's, Southeast Asia's, and colonial Europe's kilns and factories in terms of a probability distribution; a common pattern may be one in which a ceramic type is predominantly produced early within its age range, with a dwindling tail to meet the demands of consumers who wish to replace a lost or broken possession, but such a scenario would be speculation on our part. Moreover, Island Southeast Asia in general, and the remote corner of East Timor in particular, can be viewed as a secondary market in comparison to the primary export (China, Europe) and home markets (see Rinaldi 1989; Harrisson 1995), which implies that ceramic types may have been mainly exported to Island Southeast Asia during their period of waning popularity in their primary market(s) or even as secondhand wares. In the absence of specific information we will assume each probability midpoint is at the middle of its estimated date range, in effect assuming a symmetric probability distribution. For the two spits with both radiocarbon and ceramic date estimates (pit A spit 2 and pit $\mathrm{C}$ spit 2), this results in an average radiocarbon-ceramic gap of 172 and 90 years, respectively (Table 3 ). In addition, there are two radiocarbon dates with ceramic dates in an adjacent spit; these gaps each average just over 170 years. However, given the possibility that ceramics may remain in circulation long after their time of production (see Brown 2009 for examples on shipwreck sites), it may be more appropriate to use the minimum gap rather than the average gap, as this prevents ceramics that were made earlier but deposited at roughly the same time as later ceramics from contributing to the gap estimate. The minimum midpoint gap for pit A spit 2 is 126 years, while for pit $\mathrm{C}$ spit 2 it is 57 years. Radiocarbon estimate A8c has a minimum ceramic gap of 79 years to the spit immediately above it and 129 years to the spit below it, while radiocarbon estimate $\mathrm{C} 7 \mathrm{c}$ has only one ceramic in the spit below it so its minimum gap equals its average gap of 178 years. Summarizing this analysis, it appears that the gap size is between 57 and 178 years. Given the uncertain nature of the ceramic production frequency distribution, a better characterization may be simply to say that the radiocarbon dates are roughly 100 years later than the ceramics dates. 
Table 3. Radiocarbon vs. Ceramic Typology Date Gaps

\begin{tabular}{|c|c|c|c|c|c|c|c|}
\hline \multirow[b]{2}{*}{ PIT } & \multicolumn{3}{|c|}{ RADIOCARBON } & \multicolumn{3}{|c|}{ CERAMIC TYPOLOGY } & \multirow[b]{2}{*}{ RC-CERAMIC GAP } \\
\hline & ID & SPIT & MID-POINT & VESSEL ID & SPIT & MID-POINT & \\
\hline \multirow[t]{6}{*}{ A } & $\mathrm{A} 2 \mathrm{c}$ & 2 & 1826 & $\mathrm{~A} 7 \mathrm{v}$ & 2 & 1600 & 226 \\
\hline & & & & A6v & 2 & 1700 & 126 \\
\hline & & & & $\mathrm{A} 5 \mathrm{v}$ & 2 & 1700 & 126 \\
\hline & & & & $\mathrm{A} 4 \mathrm{v}$ & 2 & 1650 & 176 \\
\hline & & & & $\mathrm{A} 3 \mathrm{v}$ & 2 & 1675 & 151 \\
\hline & & & & $\mathrm{A} 2 \mathrm{v}$ & 2 & 1600 & 226 \\
\hline \multirow[t]{7}{*}{ A } & $\mathrm{A} 8 \mathrm{c}$ & 8 & 1829 & $\mathrm{~A} 17 \mathrm{v}$ & 7 & 1675 & 154 \\
\hline & & & & $\mathrm{A} 16 \mathrm{v}$ & 7 & 1700 & 129 \\
\hline & & & & $\mathrm{A} 15 \mathrm{v}$ & 7 & 1550 & 279 \\
\hline & & & & $\mathrm{A} 14 \mathrm{v}$ & 7 & 1600 & 229 \\
\hline & & & & $\mathrm{A} 12 \mathrm{v}$ & 7 & 1750 & 79 \\
\hline & & & & $\mathrm{A} 19 \mathrm{v}$ & 9 & 1700 & 129 \\
\hline & & & & $\mathrm{A} 18 \mathrm{v}$ & 9 & 1600 & 229 \\
\hline \multirow[t]{3}{*}{$\mathrm{C}$} & $\mathrm{C} 2 \mathrm{c}$ & 2 & 1832 & $\mathrm{C} 3 \mathrm{v}$ & 2 & 1700 & 132 \\
\hline & & & & $\mathrm{C} 2 \mathrm{v}$ & 2 & 1775 & 57 \\
\hline & & & & $\mathrm{C} 1 \mathrm{v}$ & 2 & 1750 & 82 \\
\hline C & $\mathrm{C} 7 \mathrm{c}$ & 7 & 1828 & $\mathrm{C} 4 \mathrm{v}$ & 8 & 1650 & 178 \\
\hline
\end{tabular}

Radiocarbon mid-point is based on 50:50 year for posterior probability distribution. Ceramic typology mid-point $=($ start year + end year $) / 2$. See text for discussion.

\section{Assessing Dates}

Are the radiocarbon dates or the ceramic dates more likely correct (assuming they are not both wrong)? One way to assess this is to evaluate (in the context of the Macapainara site) the potential sources of error in each technique that can lead to incorrect date estimates. The first error source we will consider is stratigraphic displacement, which can lead to incorrect dating of spits with either technique by vertically moving analytical material and disrupting the original association between material and deposition spit. As previously discussed, stratigraphic displacement does not seem to be a problem in Macapainara excavation pits A and C. Here we will simply point out that, in addition to the arguments in favor of stratigraphic integrity presented previously, it seems unlikely stratigraphic displacement would operate in only one direction, and it is therefore unlikely to produce the pattern seen in pits $\mathrm{A}$ and $\mathrm{C}$ with radiocarbon dates being consistently younger than ceramic dates. When stratigraphy is disturbed by human or animal digging, we would expect a mixing of materials and dates such as is seen in Macapainara excavation pit D, rather than the shifting of one type of material consistently up or down while the other remains in place or shifts in the opposite direction. The pattern found at Macapainara pits $\mathrm{A}$ and $\mathrm{C}$ is more likely the result of a process that affects only one of the dating techniques.

Radiocarbon analysis is a complex and delicate procedure, so most archaeologists have experienced receiving radiocarbon dates from analytical labs that do not match the known archaeological context. These dates are therefore considered suspect. The dates in this study, however, are accelerator mass spectrometry dates on charcoal, which is one of the best radiocarbon analytical situations. In addition, the dates are recent enough to be in a well-understood portion of the southern hemisphere radio- 
carbon calibration curve (SHCal04). It is very unlikely that there is significant analytical error beyond that incorporated in the radiocarbon probability distributions or that analytical error would produce the consistent too-young pattern needed to explain our results.

Radiocarbon dates are subject to what is often called the "old wood" problem. Radiocarbon dates the time when a plant died, rather than the date when it was used by humans and then deposited into archaeological context. Because dead wood can remain in the natural environment for many years prior to use, this can lead to incorrectly old radiocarbon dates. That, however, is not the problem here, where the radiocarbon dates appear to be too young in comparison to the ceramic dates. If some of the Macapainara samples suffer from the old wood problem, then the gap between radiocarbon and ceramic dates would be even bigger than it currently appears.

Another problem that can arise with radiocarbon dating is non-anthropogenic origin of the source material. Natural fires produce charcoal that then may find its way into the archaeological context, creating a false association with cultural materials. This is possible when, as in the current instance, the source material is not taken from hearths or other obviously anthropogenic features. We consider this unlikely in the Macapainara context because there is no reason to expect redeposition of natural charcoal to lead to a pattern of consistently too-young dates, and it seems unlikely that natural, newer charcoal would mix with abundant older cultural remains including marine shell and ceramics without at least disturbing the stratigraphic integrity.

Since it seems that the Macapainara radiocarbon dates are not the source of the date gap, we should consider possible ceramic dating error sources. The accuracy of ceramic dating depends on the date accuracy of pre-established typologies, the distinctiveness among typologies, and the ability of the analyst to correctly make type assignments to small potsherds. In the current instance, assignments were made by an experienced analyst who has produced a statistically based seriation of the ceramic types covered here (Bulbeck 1996-1997) and who also made appropriate reference to subsequent dating work based on shipwreck ceramics (Brown 2009). While it is always possible that some potsherds have been incorrectly assigned or that particular types may have incorrect date associations, there is no reason to expect that such errors would produce our consistent pattern of too-old ceramic dates in comparison to the radiocarbon dates. More likely, it would produce a scattering of dates resulting in either no pattern or a false indication of stratigraphic displacement. Note also that the Macapainara potsherds are assigned to types originating in four or five different regions but, with the possible exception of the single European potsherd $(\mathrm{A} 12 \mathrm{v})$ in spit A7, produce date ranges that are internally consistent across different regions. While the tendency of Chinese kilns to produce imitations of antique wares is recognized as a problem in classifying Chinese ceramics (e.g., Harrisson 1995), it seems unlikely that types from different regions would have incorrect but consistent date assignments.

Ceramic typology dates from terrestrial archaeological sites are terminus post quem dates, in that the date range for each type is estimated on its likely time of production (e.g., Rinaldi 1989; Harrisson 1995; Hein 2001) or trade (e.g., Brown 2009), rarely its time of entering the archaeological record (but see Guy [1986:45-47] and Harrisson [1990:33-43]). Excluding special circumstances such as funerary depositions, 
for which there is no evidence at Macapainara, ceramic potsherds enter the archaeological record when a portion of a vessel breaks and the resulting potsherd or broken vessel is discarded or lost. A carefully handled vessel may last centuries, stored away as a heirloom and/or displayed only on ceremonial occasions (e.g., Harrisson 1990), resulting in potsherd deposition long after the time when it would be expected based on the vessel's classification. As noted previously, the vast majority of the pottery at Macapainara consisted of nonexotic earthenware, which implies that the small quantities of exotic high-fired ceramics owned by the inhabitants would have been carefully curated and rarely used except for display or ceremonial purposes. This appears to be the likely explanation for the time gap between radiocarbon and ceramic typology dates found at Macapainara. It is also possible that the Timorese were given particularly old vessels in trade, or that the occupants who established Macapainara had decided to bring their heirlooms to their fortified residence, but these points would merely reiterate the unreliability of the ceramic dates ascertained for the site.

\section{CONCLUSIONS}

Radiocarbon and ceramic typology dating produces different results at Macapainara, with the ceramic dates consistently older than expected when compared to the radiocarbon dates. The size of the gap is difficult to assess given the uncertainties associated with each dating technique and may vary over time, but is estimated to average about 100 years. Stratigraphy within at least two of the three excavation pits appears to be good and in any case stratigraphic displacement is unlikely to produce such a consistent pattern. Given the nature and consistency of the pattern found, it is most likely that the gap is the result of long and effective conservation of fine ceramic vessels by the Macapainara inhabitants.

Thus it is best to rely on the radiocarbon dates rather than the ceramic dates when assessing questions such as whether the start of occupation at Macapainara corresponds with an early, climatologically driven start to fortifications in East Timor or a somewhat later, contact-driven model. This supports the radiocarbon-based analysis of O'Connor et al. (2012), which concludes that fortification construction in eastern East Timor was driven by resource imbalances caused by social factors such as sandalwood trading rather than by environmental change.

Although the current assessment only involves the single site of Macapainara, our results may be widely applicable within East Timor and indeed throughout Island Southeast Asia where access to fine ceramics relied on importing vessels from China, Mainland Southeast Asia, and later, Europe. Prolonged conservation of rare vessels is likely to be common in such circumstances, leading to falsely old ceramic dates. We are aware that ceramic dating may be more applicable to trade-based palace sites in Island Southeast Asia, where the massive quantities of stoneware and porcelain indicate their use in day-to-day material culture, but even here a proportion of the vessels date to several centuries earlier than the earliest suspected use of the site as a palace center (e.g., Harrisson 1990:33-43; Bulbeck 1992:371-372). Particularly in the case of sites with merely a small assemblage of fine ceramics, radiocarbon dating is the preferred method in obtaining a reliable chronology. If a lack of organic preservation or funding limitations prevents radiocarbon analysis, then any use of ceramic dates must account for the likelihood that most if not all such dates have the status of terminus post quem determinations and may well be misleadingly early in time. 


\section{ACKNOWLEDGMENTS}

The authors would like to thank Professor Sue O'Connor and Dr. Celia Brockwell for providing access to Macapainara samples, radiocarbon results, and excavation notes.

\section{REFERENCES CITED}

Brown, Roxanna Maude

2009 The Ming Gap and Shipwreck Ceramics in Southeast Asia. Bangkok: The Siam Society.

Buck, Caitlin E., J. Andrés Christen, and Gary N. James

1999 BCal: An On-Line Bayesian Radiocarbon Calibration Tool. Internet Archaeology 7. http://intarch.ac.uk/journal/issue7/buck_index.html.

Bulbeck, David

1992 A Tale of Two Kingdoms. The Historical Archaeology of Gowa and Tallok, South Sulawesi, Indonesia. Ph.D. diss. The Australian National University, Canberra.

1996- The Bronze-Iron Age of South Sulawesi, Indonesia: Mortuary traditions, metallurgy and 1997 trade. In Ancient Chinese and Southeast Asian Bronze Age Cultures, vol. II: 1007-1076, ed. F. David Bulbeck and Noel Barnard. Taipei: Southern Materials Center Inc.

2010 Tradeware and Glass Sherds, and Beads and other Ornaments excavated at Macapainara, East Timor, in 2008: Final Report. Unpublished manuscript, dated April 2, 2010. Available from the author.

Bulbeck, David, and Ian Caldwell

2000 Land of Iron: The Historical Archaeology of Luwu and the Cenrana Valley. Hull, University of Hull Centre for South-East Asian Studies.

DunNell, Robert C.

1970 Seriation method and its evaluation. American Antiquity 35:305-319.

Fenner, Jack N., Celia Brockwell, and Sue O’Connor

forth- Bayesian musings on the dating of the fortified settlement at Macapainara, East coming Timor. In Forts and Fortification in Wallacea: Archaeological and Ethnohistoric Investigations, ed. Sue O’Connor, Andrew McWilliam, and Sally Brockwell. Terra Australis. Canberra: ANU E-Press.

Field, J. S., AND P. V. LAPE

2010 Paleoclimates and the emergence of fortifications in the tropical Pacific islands. Journal of Anthropological Archaeology 29(1): 113-124.

GuY, John S.

1986 Oriental Trade Ceramics in South-East Asia Ninth to Sixteenth Centuries. Oxford: Oxford University Press.

HARrisSON, BARBARA

1990 Pusaka: Heirloom Jars of Borneo. Oxford: Oxford University Press.

1995 Later Ceramics in South-East Asia: Sixteenth to Twentieth Centuries. Oxford, Oxford University Press.

HeIn, DonN

2001 The Sawankhalok Ceramic Industry: From Domestic Enterprise to Regional Entrepreneur. Ph.D. diss. Deakin University, Melbourne.

Lape, Peter V.

2006 Chronology of fortified settlements in East Timor. Journal of Island and Coastal Archaeology $1: 285-297$.

Lape, Peter V, and Chao Chin-Yung

2008 Fortification as a human response to Late Holocene climate change in East Timor. Archaeology in Oceania $43: 11-21$.

McCormac, F. G., A. G. Hogg, P. G. Blackwell, C. E. Buck, T. F. G. Higham, and P. J. Reimer 2004 SHCal04 Southern Hemisphere calibration, 0-11.0 cal kyr BP. Radiocarbon 46(3):10871092.

O’Connor, Sue, Andrew McWilliam, and Sally Brockwell

forth- Forts and Fortification in Wallacea: Archaeological and Ethnohistoric Investigations. Terra Australis. coming Canberra: ANU E-Press. 
O’Connor, Sue, Andrew McWilliam, Jack N. Fenner, and Sally Brockwell

2012 Examining the origin of fortifications in East Timor: Social and environmental factors. The Journal of Island and Coastal Archaeology 7:200-218.

Reid, ANTHONy, ED.

1983 Slavery, Bondage and Dependency in Southeast Asia. St. Lucia: University of Queensland Press.

Rinaldi, MaUra

1989 Kraak Porcelain: A Moment in the History of Trade. London: Bamboo Publishing Ltd.

South, Stanley

1977 Method and Theory in Historical Archaeology. New York: Academic Press.

\begin{abstract}
Radiocarbon analysis and ceramic typology assessment are commonly used to date late Holocene archaeological sites in Island Southeast Asia. We apply both methods to date the site of Macapainara in East Timor, and they produce substantially different age ranges for this site. The radiocarbon dates are consistently later in time than ceramic typology dates from the same or adjacent stratigraphic levels. We assess the various sources of error for the two dating techniques that could produce this discrepancy, and conclude that the ceramic typology age ranges are misleadingly old due to concerted curation of fine ceramics by the site occupants. We discuss the implications of this for dating sites in East Timor and elsewhere within Island Southeast Asia. KeYwords: radiocarbon dating, relative dating, ceramic typology, Macapainara, East Timor, Island Southeast Asia, ceramics in Southeast Asia.
\end{abstract}

